Original Research

\title{
Assessing Greenhouse Gas Emissions from Conventional Farms Based on the Farm Accountancy Data Network
}

\author{
Alina Syp ${ }^{1 *}$, Dariusz Osuch ${ }^{2}$ \\ ${ }^{1}$ Department of Bioeconomy and Systems Analysis, Institute of Soil Science and Plant Cultivation, \\ State Research Institute, 8 Czartoryskich Str., 24-100 Puławy, Poland \\ ${ }^{2}$ Agricultural Accountancy Department, Institute of Agricultural and Food Economics, National Research Institute, \\ 20 Świętokrzyska Str., 00-002 Warszawa, Poland
}

Received: 6 July 2017

Accepted: 26 August 2017

\begin{abstract}
Our paper uses the Intergovernmental Panel on Climate Change (IPCC) guidelines in combination with the Farm Accountancy Data Network (FADN) to estimate agricultural greenhouse gas emissions at the farm level. The study adopts a cross-cutting approach that combines emissions related to different categories (agriculture and energy/fuel). Overall, the aim was to assess the intensities of emissions from conventional farms classified according to production type, economic size, and utilized agricultural area (UAA). The results show that large variations in farms justify the micro approach to farm evaluation. Applying the methodology revealed that conventional dairy farm types, medium-small $(25 \leq €<50)$ and medium-large $(20<=\mathrm{UAA}<30)$, were characterized by the highest GHG emissions intensity indexes compared to other farm types and sizes. The FADN originally was developed for evaluating the income of agricultural holdings and the impact of the Common Agricultural Policy (CAP). However, our study demonstrates that the current FADN database could also be used to provide indirect information on environmental farm performance, identify differences between farm types, and give insight into the environmental impact caused by the agricultural sectors in European countries. These results may also be useful for farm advisors to benchmark some aspects of farm environmental performance using farm financial data.
\end{abstract}

Keywords: emission intensity, FADN data, farm indicators, GHG emissions

\section{Introduction}

The agricultural sector in Poland accounted for $8 \%$ of the country's total greenhouse gas (GHG) emissions

*e-mail: asyp@iung.pulawy.pl in 2014 [1]. It was the second largest source after the energy sector (81.3\%) [1]. From 1988 to 2014 in Poland, GHG emissions from agriculture have decreased by $36 \%$, whereas in the European Union (EU) the decrease has been 24\% since 1990 [1-2]. The reduction of GHG emissions from agriculture was a consequence of implementing the following EU policies: Nitrate, Landfill Waste, and Renewable Energy Directives (RED), and the 
Common Agricultural Policy (CAP) [3]. The mitigation of GHG emissions was one of the main factors shaping the assumptions of CAP for the period 2014-20. The EU sets the GHG emissions reduction targets for short-, medium-, and long-term framework. The goal of the first period to the year 2020 is to cut GHG emissions by $20 \%$ in 2020 in comparison to the 1990 level [4]. The midterm perspective for the year 2030 defined binding targets by at least $40 \%$ GHG reduction by 2030 - to below the 1990 level [5]. To achieve this objective, GHG emissions should be cut by 43 and 30\% (compared to 2005), respectively, in Emission Trading Sectors (ETS) and in non-ETS sectors (where agriculture is included). The long-term plan for 2050 suggests a reduction of GHG emissions to $80-95 \%$ by 2050 below the 1990 level, and the agricultural sector will have to cut its emissions by $42-49 \%$ [6].

Monitoring and reporting GHG emissions is a crucial step in each regulation related to the reduction of GHG emissions. In order to fulfill the commitments made under the United Nations Framework Convention on Climate Change (UNFCCC) and the European GHG emissions monitoring and reporting mechanism, each EU member state is obliged to prepare an annual National Inventory Report, which is the official tool for monitoring GHG emissions [1].

Within the framework of UNFCCC, the Intergovernmental Panel on Climate Change (IPCC) has been responsible for developing common methodology for estimating emissions and removals of GHG from all sectors [7]. The IPCC Guidelines determinate three calculation methods (Tiers) based on available data [7]. Tier 1 methodology uses the default emissions factor provided by IPCC, assuming a linear relationship between emissions and activities data. The Tier 2 approach determines GHG emissions by adopting country- or region-specific emission factors indicating local pedoclimatic conditions. The Tier 3 method applies biogeochemical models. The Tier 1 and 2 methodologies require simple and accessible data, assuming that the sample data represent the full population, and, therefore, are appropriate for large-scale applications and for reporting.

Because agriculture is one of the most important sectors, in this context an appropriate assessment of emissions is one of the most difficult challenges [8]. Agricultural GHG emissions are a typical example of pollution originating from various sources, and then these emissions must be calculated indirectly. As stated before, the common indirect estimation methodology has been developed by the IPCC and is recognized globally as a standard related to aggregated data and does not appear to be particularly appropriate for micro data [7]. Coderoni et al. [9] adapted and applied the IPCC methodology in combination with data from the Farm Accountancy Data Network (FADN) to estimate GHG emissions at the farm level in Italy. The objective of FADN is to provide microeconomic data for evaluating the income of agricultural holdings and the impact of CAP for all EU member states. However, more and more often, FADN is used to assess environmental farm performance. Nevens et al. [10] used FADN data to examine $\mathrm{N}$ balances in dairy farms in Belgium. Westbury et al. [11] applied FADN data to the agri-environmental footprint index (AFP) to measure the environmental impact of three different types of agriculture in England. Gerrard et al. [12] used FADN data to compare environmental performance of organic and conventional farms. They stated that FADN could provide data to evaluate some aspects of farm environmental performance across many countries and access changes over time. Buckley et al. [13], based on FADN, applied a micro-level methodological approach to develop $\mathrm{N}$ and $\mathrm{P}$ sustainability indicators across a range of farm systems in the Republic of Ireland. Corson et al. [14] used FADN data to estimate emission inventories of French farms.

Coderoni et al. [9] stated that the use of FADN data has the advantage of making data collection on farm activities easier and standardized through all the different agricultural practices and farm types. In addition, using FADN data enables us to connect GHG emissions with other farm economic indicators, allowing for a defining hypotheses about possible causes of various emission intensities. By using FADN farm data connected to main agricultural activities, Coderoni et al. [9] estimated methane $\left(\mathrm{CH}_{4}\right)$, nitrous oxide $\left(\mathrm{N}_{2} \mathrm{O}\right)$, and carbon dioxide $\left(\mathrm{CO}_{2}\right)$ emissions in the following categories: animal and crop production, fertilizers, fuel, and land use. This approach makes it possible to compare emissions at different levels at a farm. In addition, it allows us to assess emission variations between farms due to economic size, type, utilized agricultural area (UAA), and location. Because they are strictly connected to farm production, the obtained values relate only to emissions that arise within the boundaries of the farm. In this method, the emissions resulted from the production of agricultural inputs, and transport of inputs and products are not taken into account. This "farm gate" approach in emissions estimation at the farm level has some benefits. The first advantage is to enable the farmer to control GHG emissions at each production stage and adjust the management practices to make them more environmentally friendly [15]. Secondly, this method provides the possibility of evaluating farm-level policies - mainly those that affect farmers' behavior in terms of choice of production technology and agricultural inputs applied.

The aim of our research was to assess environmental performance of conventional farms in Poland by estimating GHG emissions at the farm level and emissions intensity using FADN data.

\section{Material and Methods}

The methodology for estimating GHG emissions at farm level, as proposed in this study, is based on the adaptation of the IPCC methods [7] combined with the farm agricultural production data from the Polish 
Table. 1 Emissions sources of the agricultural sector.

\begin{tabular}{|c|c|c|}
\hline IPCC Category & Source & GHG \\
\hline $3 \mathrm{~A}$ & Enteric fermentation & $\mathrm{CH}_{4}$ \\
\hline $3 \mathrm{~B}$ & $\begin{array}{c}\text { Manure } \\
\text { management }\end{array}$ & $\mathrm{N}_{2} \mathrm{O}, \mathrm{CH}_{4}$ \\
\hline $3 \mathrm{D}$ & Agricultural soils & $\mathrm{N}_{2} \mathrm{O}$ \\
\hline $3 \mathrm{G}$ & Urea & $\mathrm{CO}_{2}$ \\
\hline $1 \mathrm{~A}$ & Energy & $\mathrm{CO}_{2}$ \\
\hline
\end{tabular}

Source: IPCC 2006

FADN database. According to IPCC methodology, the "Agriculture" sector (referring to agricultural holdings) emits principally two greenhouse gasses $-\mathrm{CH}_{4}$ and $\mathrm{N}_{2} \mathrm{O}$ - in nine different categories, six of which are estimated in the National Centre for Emission Management (KOBiZE) GHG inventory reports because they occur in Polish conditions. These include: enteric fermentation, manure management, agricultural soils, filed burning of agricultural residues, and liming and urea fertilization. Emissions of $\mathrm{CO}_{2}$ from the use of machinery, farm buildings, and transport of agricultural products are classified in the "energy" sector. Furthermore, emissions and removal of $\mathrm{CO}_{2}$ from agricultural soils and biomass are accounted for in the land use, land use change, and forestry (LULUCEF) sector. However, for appropriate assessment of GHG emissions at farm level the adopted methodology has been used, including emissions classified in two different sectors, i.e., agriculture and energy. All the sources of GHG emissions included in the applied methodology are presented in Table 1. In order to express emissions in $\mathrm{CO}_{2}$ equivalents, the individual emissions $\left(\mathrm{N}_{2} \mathrm{O}, \mathrm{CH}_{4}\right.$, and $\left.\mathrm{CO}_{2}\right)$ were multiplied by the Global Warming Potential (GWP) index. The values of GWP in a 100-year time frame are: 1 for $\mathrm{CO}_{2}, 298$ for $\mathrm{N}_{2} \mathrm{O}$, and 25 for $\mathrm{CH}_{4}$ [16]. In this study the IPCC emission factors were used to estimate GHG emissions. However, to reflect the specifics of national conditions some emission factors developed for Poland were applied, too. Those indicators are presented in official reports prepared by KOBiZE, which in Poland is responsible for compiling the GHG inventory for the purposes of the European Union and UNFCCC $[1,7]$. GHG emissions from various sources were aggregated into four categories: animal production, crop production, fertilizers, and fuel. Table 2 presents the data from the FADN database that was used to estimate the individual emission categories.

Since the FADN database was not designed to collect the data needed to estimate GHG emissions at the farm level, some assumptions were necessary in order to complete the relevant data for calculating emissions by the four categories mentioned above. GHG emissions from livestock production include emissions from enteric fermentation and manure management. Enteric fermentation is a process including anaerobic decomposition of fibers derived from roughage. The amount of $\mathrm{CH}_{4}$ emitted depends on the following factors: type, age, and weight of the animal, quantity and quality of the feed, and energy requirements. Two methods

Table 2. Summary of GHG emission sources considered and the respective FADN data applied.

\begin{tabular}{|c|c|c|}
\hline Emission source & Emission category & FADN data \\
\hline $\mathrm{N}_{2} \mathrm{O}$ manure management & Animal production & Animal numbers \\
\hline $\mathrm{CH}_{4}$ manure management & Animal production & Animal numbers \\
\hline $\mathrm{CH}_{4}$ Enteric fermentation & Animal production \\
\hline \multicolumn{2}{|c|}{$\mathrm{N}_{2} \mathrm{O}$ agricultural soil } \\
\hline Use of $\mathrm{N}$ mineral fertilizers & $\mathrm{N}_{2} \mathrm{O}$ direct emissions & N quantities \\
\hline Use of $\mathrm{N}$ organic fertilizers & Fertilizers & Animal numbers \\
\hline Crop residues & Fertilizers & Animal numbers \\
\hline Urine and dung depositing by grazing & Crop production & Crop area (UAA) and crop yield \\
\hline animals & Crop production & N quantities / Animal numbers \\
\hline Atmospheric deposition & $N_{2} \mathrm{O}$ indirect emissions & yield \\
\hline Leaching and run-off & Fertilizers & N quantities / Animal numbers / area and crop \\
\hline $\mathrm{CO}_{2}$ Urea & Fertilizers & Fuel quantities \\
\hline $\mathrm{CO}_{2}$ Energy & Fertilizers & Fuel \\
\hline
\end{tabular}

Source: Our own elaboration based on Coderoni et al. 2013 
were used for estimating $\mathrm{CH}_{4}$ emissions from enteric fermentation. The first, simplified, was based on the default values recommended by the IPCC, and the second used country emission factors. The Tier 1 method was applied in emissions estimation for pigs, goats, and horses, and Tier 2 for cattle. The country $\mathrm{CH}_{4}$ emission factors for ruminants have been developed on the basis of daily animal energy requirements. $\mathrm{CH}_{4}$ emissions from poultry were not estimated due to the lack of IPCC guidelines. The total amount of $\mathrm{CH}_{4}$ emissions from enteric fermentation were calculated as a ratio of the annual average number of animals in each category and the emission factor (EF).

The next important source of $\mathrm{CH}_{4}$ emissions was animal excrement decomposing under anaerobic conditions. The resulting amount of $\mathrm{CH}_{4}$ fluxes depended on the weight of the excrement and storage technology. The $\mathrm{CH}_{4}$ emissions from ruminant and non-ruminant manure were estimated using country emission factors developed in agreement with IPCC methodology. The emission factors, as in enteric fermentation, depend on the animals' daily demand for energy and their maintenance system. The amount of $\mathrm{CH}_{4}$ emitted from manure management was obtained by multiplying the average annual animal number and specific EF. Within this category emissions from the burning of manure and those occurring during biogas production were not included. During the storage of animal excrement beyond $\mathrm{CH}_{4}$ emissions into the atmosphere there is also $\mathrm{N}_{2} \mathrm{O}$ emission. Estimations of $\mathrm{N}_{2} \mathrm{O}$ emissions at Tier 2 were based on national data on livestock maintenance systems
[1]. The basis for calculating the amount of nitrogen $(\mathrm{N})$ in animal excrement were the country standard coefficients based on the quantity and digestibility of feed. As the FADN database contains very detailed data on livestock, in GHG emissions estimation weight and age categories of animals were taken into account. In our study, GHG emissions from plant production included $\mathrm{N}_{2} \mathrm{O}$ emissions from crop residues and urine and dung deposited by grazing animals.

The analysis omitted emissions from organic soils, because none of the households had this type of soil. The $\mathrm{N}_{2} \mathrm{O}$ emissions from crop residues were estimated on the basis of the area of each crop and their yields. Calculations of $\mathrm{N}_{2} \mathrm{O}$ emissions resulting from animal urine and dung deposited on pastures were based on animal population and amount of nitrogen content in animal excreta. In the calculation of $\mathrm{N}_{2} \mathrm{O}$ emissions from crop production, country-specific parameters applied in the national GHG inventory reports and the default emission values were used. GHG emissions from fertilizers constitute another category occurring at the farm. This includes emissions from the use of: mineral and organic fertilizers, urea, atmospheric deposition, and nitrogen leaching and runoff. Calculations of these emissions were based on the FADN data on: the amount of nitrogen and urea used, animal population, crop area, and the yield of each plant on the farm. For each of these emission sources the default values were taken from the IPCC [7]. In order to estimate the GHG emissions associated with fuel consumption on the farm, the $\mathrm{CO}_{2}$ emission factor for Europe from the

Table 3. Economic and environmental farm level data for different farm types; standard deviations are shown in brackets.

\begin{tabular}{|c|c|c|c|c|c|c|c|c|c|c|}
\hline Variable & Unit & Total & $\begin{array}{l}\text { Field } \\
\text { crops }\end{array}$ & $\begin{array}{l}\text { Perm. } \\
\text { crops }\end{array}$ & Fruits & Dairy & $\begin{array}{l}\text { Grazing } \\
\text { livestock }\end{array}$ & Pigs & Poultry & $\begin{array}{l}\text { Mixed } \\
\text { crops and } \\
\text { livestock }\end{array}$ \\
\hline \multicolumn{11}{|l|}{ Economic data } \\
\hline Farm represented & & 688,967 & 136,104 & 28,353 & 30,644 & 93,350 & 30,013 & 25,814 & 4,769 & 339,922 \\
\hline Sample farms & & 11,701 & 3,185 & 348 & 402 & 2,703 & 428 & 768 & 73 & 3,794 \\
\hline Economic size & Euro & 47,557 & 43,330 & 72,318 & 25,369 & 49,881 & 32,827 & 100,578 & 216,776 & 37,204 \\
\hline $\begin{array}{l}\text { Total utilized } \\
\text { agricultural area }\end{array}$ & ha & 36 & 55 & 7 & 14 & 32 & 31 & 33 & 23 & 29 \\
\hline $\begin{array}{l}\text { Total livestock unit } \\
\text { (LU) }\end{array}$ & LU & 28 & 3 & 1 & 0 & 41 & 31 & 108 & 200 & 25 \\
\hline Total output & PLN & 235,075 & 241,512 & 379,157 & 181,707 & 234,824 & 119,276 & 440,615 & $1,689,403$ & 165,764 \\
\hline \multicolumn{11}{|l|}{ Emissions data } \\
\hline GHG farm & $\mathrm{MgCO}_{2}$ eq. & $\begin{array}{c}96.47 \\
(113.8)\end{array}$ & $\begin{array}{c}65.4 \\
(80.4)\end{array}$ & $\begin{array}{c}14.0 \\
(19.2)\end{array}$ & $\begin{array}{c}12.6 \\
(14.2)\end{array}$ & $\begin{array}{c}184.9 \\
(144.2)\end{array}$ & $\begin{array}{c}108.2 \\
(119.6)\end{array}$ & $\begin{array}{c}111.4 \\
(121.9)\end{array}$ & $\begin{array}{c}93.9 \\
(87.9)\end{array}$ & $\begin{array}{c}71.3 \\
(80.0)\end{array}$ \\
\hline Emission intensity & $\begin{array}{l}\mathrm{g} \mathrm{CO}_{2} \text { eq. } \\
\mathrm{PLN}^{-1}\end{array}$ & $\begin{array}{c}410 \\
(300)\end{array}$ & $\begin{array}{l}270 \\
(270)\end{array}$ & $\begin{array}{c}40 \\
(20)\end{array}$ & $\begin{array}{l}70 \\
(70)\end{array}$ & $\begin{array}{c}790 \\
(590)\end{array}$ & $\begin{array}{c}910 \\
(830)\end{array}$ & $\begin{array}{l}250 \\
(170)\end{array}$ & $\begin{array}{c}60 \\
(60)\end{array}$ & $\begin{array}{c}430 \\
(420)\end{array}$ \\
\hline $\begin{array}{l}\text { Emission intensity } \\
\text { per ha }\end{array}$ & $\underset{\mathrm{ha}^{-1}}{\mathrm{Mg} \mathrm{CO}}$ eq. & $\begin{array}{c}2.7 \\
(2.7)\end{array}$ & $\begin{array}{c}1.2 \\
(1.3)\end{array}$ & $\begin{array}{c}2.1 \\
(1.9)\end{array}$ & $\begin{array}{c}0.9 \\
(1.3)\end{array}$ & $\begin{array}{c}5.7 \\
(6.4)\end{array}$ & $\begin{array}{c}3.5 \\
(3.3)\end{array}$ & $\begin{array}{c}3.3 \\
(3.3)\end{array}$ & $\begin{array}{c}4.1 \\
(2.8)\end{array}$ & $\begin{array}{c}2.5 \\
(2.9)\end{array}$ \\
\hline $\begin{array}{l}\text { Emission intensity } \\
\text { per LU }\end{array}$ & $\underset{\mathrm{LU}^{-1}}{\mathrm{Mg} \mathrm{CO}}$ & $\begin{array}{c}3.5 \\
(2.11)\end{array}$ & $\begin{array}{c}2.2 \\
(9.5)\end{array}$ & $\begin{array}{l}24.3 \\
(7.9)\end{array}$ & - & $\begin{array}{c}4.5 \\
(4.6)\end{array}$ & $\begin{array}{c}3.5 \\
(3.9)\end{array}$ & $\begin{array}{l}1.0 \\
(9.1)\end{array}$ & $\begin{array}{c}0.5 \\
(0.4)\end{array}$ & $\begin{array}{l}2.8 \\
(2.9)\end{array}$ \\
\hline
\end{tabular}

Source: own calculation based on FADN data 
Table 4. Economic and environmental farm level data for different economic farm sizes. Standard deviations are shown in brackets.

\begin{tabular}{|c|c|c|c|c|c|c|c|c|}
\hline Variable & Unit & Total & $\begin{array}{l}\text { Very small } \\
(2,000 \leq € \\
<8,000)\end{array}$ & $\begin{array}{c}\text { Small } \\
(8,000 \leq € \\
<25,000)\end{array}$ & $\begin{array}{c}\text { Medium-small } \\
(25,000 \leq € \\
<50,000)\end{array}$ & $\begin{array}{c}\text { Medium-large } \\
(50,000 \leq € \\
<100,000)\end{array}$ & $\begin{array}{c}\text { Large } \\
(100,000 \leq € \\
<500,000)\end{array}$ & $\begin{array}{c}\text { Very large } \\
(€ \leq 500,000)\end{array}$ \\
\hline \multicolumn{9}{|l|}{ Economic data } \\
\hline Farm represented & & 688,967 & 254,311 & 291,725 & 92,997 & 34,684 & 14,726 & 524 \\
\hline Sample farms & & 11,701 & 558 & 3,848 & 3,726 & 2,530 & 1,019 & 20 \\
\hline Economic size & Euro & 47,557 & 6,523 & 16,253 & 36,093 & 68,716 & 162,590 & 813,586 \\
\hline $\begin{array}{l}\text { Total utilized agricul- } \\
\text { tural area }\end{array}$ & ha & 36 & 9 & 16 & 30 & 52 & 104 & 152 \\
\hline $\begin{array}{l}\text { Total livestock unit } \\
\text { (LU) }\end{array}$ & LU & 28 & 2 & 8 & 20 & 42 & 98 & 772 \\
\hline Total output & PLN & 235,075 & 29,639 & 74,979 & 168,161 & 333,175 & 871,356 & $4,407,207$ \\
\hline \multicolumn{9}{|l|}{ Emissions data } \\
\hline GHG farm & $\begin{array}{l}\mathrm{Mg} \mathrm{CO}_{2} \\
\text { eq. }\end{array}$ & $\begin{array}{c}96.47 \\
(113.8)\end{array}$ & $\begin{array}{l}10.2 \\
(6.3)\end{array}$ & $\begin{array}{c}30.6 \\
(22.1)\end{array}$ & $\begin{array}{c}83.7 \\
(49.3)\end{array}$ & $\begin{array}{c}159 \\
(92.3)\end{array}$ & $\begin{array}{l}274.3 \\
(216.4)\end{array}$ & $\begin{array}{c}568.3 \\
(406.5)\end{array}$ \\
\hline Emission intensity & $\begin{array}{l}\mathrm{g} \mathrm{CO}_{2} \text { eq. } \\
\text { PLN }^{-1}\end{array}$ & $\begin{array}{l}410 \\
(300)\end{array}$ & $\begin{array}{l}350 \\
(370)\end{array}$ & $\begin{array}{c}410 \\
(400)\end{array}$ & $\begin{array}{c}500 \\
(580)\end{array}$ & $\begin{array}{c}480 \\
(650)\end{array}$ & $\begin{array}{l}310 \\
(320)\end{array}$ & $\begin{array}{c}130 \\
(140)\end{array}$ \\
\hline $\begin{array}{l}\text { Emission intensity } \\
\text { per ha }\end{array}$ & $\begin{array}{l}\mathrm{Mg} \mathrm{CO} 2 \\
\text { eq. ha-1 }\end{array}$ & $\begin{array}{c}2.7 \\
(2.7)\end{array}$ & $\begin{array}{l}1.2 \\
(1.1)\end{array}$ & $\begin{array}{l}1.9 \\
(2.7)\end{array}$ & $\begin{array}{c}2.7 \\
(5.9)\end{array}$ & $\begin{array}{c}3.1 \\
(3.1)\end{array}$ & $\begin{array}{l}2.6 \\
(2.4)\end{array}$ & $\begin{array}{l}3.7 \\
(2.1)\end{array}$ \\
\hline $\begin{array}{l}\text { Emission intensity } \\
\text { per LU }\end{array}$ & $\begin{array}{l}\mathrm{Mg} \mathrm{CO} \\
\text { eq. } \mathrm{LU}^{-1}\end{array}$ & $\begin{array}{c}3.5 \\
(2.11)\end{array}$ & $\begin{array}{l}4.1 \\
(2.7)\end{array}$ & $\begin{array}{c}4.1 \\
(3.1)\end{array}$ & $\begin{array}{c}4.2 \\
(3.4)\end{array}$ & $\begin{array}{l}3.8 \\
(3.2)\end{array}$ & $\begin{array}{l}2.8 \\
(2.4)\end{array}$ & $\begin{array}{c}0.7 \\
(1.1)\end{array}$ \\
\hline
\end{tabular}

Source: Our own calculation based on FADN data

Table 5. Economic and environmental farm-level data for farms divided according to utilized agricultural area; standard deviations are shown in brackets.

\begin{tabular}{|c|c|c|c|c|c|c|c|c|}
\hline Variable & Unit & Total & $\begin{array}{l}\text { Very small } \\
(\leq 5 \mathrm{ha})\end{array}$ & $\begin{array}{c}\text { Small } \\
(5 \leq 10 \mathrm{ha})\end{array}$ & $\begin{array}{c}\text { Medium-small } \\
(10 \leq 20 \mathrm{ha})\end{array}$ & $\begin{array}{l}\text { Medium-large } \\
(20 \leq 30 \mathrm{ha})\end{array}$ & $\begin{array}{c}\text { Large } \\
(30 \leq 50 \mathrm{ha})\end{array}$ & $\begin{array}{l}\text { Very large } \\
(>50 \text { ha })\end{array}$ \\
\hline \multicolumn{9}{|l|}{ Economic data } \\
\hline Farm represented & & 688,967 & 62,079 & 219,529 & 247,307 & 83,446 & 50,445 & 26,161 \\
\hline Sample farms & & 11,701 & 337 & 1,114 & 3,237 & 2,314 & 2,454 & 2,245 \\
\hline Economic size & Euro & 57,603 & 59,137 & 17,650 & 23,810 & 36,705 & 52,986 & 100,152 \\
\hline $\begin{array}{l}\text { Total utilized agricul- } \\
\text { tural area }\end{array}$ & ha & 36 & 2 & 8 & 15 & 25 & 39 & 94 \\
\hline $\begin{array}{c}\text { Total livestock unit } \\
\text { (LU) }\end{array}$ & LU & 28 & 22 & 7 & 16 & 27 & 37 & 49 \\
\hline Total output & PLN & 235,075 & 416,998 & 80,893 & 106,550 & 168,120 & 249,221 & 523,141 \\
\hline \multicolumn{9}{|l|}{ Emission data } \\
\hline GHG farm & $\begin{array}{l}\mathrm{MgCO}_{2} \\
\text { eq. }\end{array}$ & $\begin{array}{c}96.47 \\
(113.8)\end{array}$ & $\begin{array}{c}16.2 \\
(40.6)\end{array}$ & $\begin{array}{c}18.3 \\
(19.2)\end{array}$ & $\begin{array}{c}46.6 \\
(43.7)\end{array}$ & $\begin{array}{c}85.1 \\
(64.0)\end{array}$ & $\begin{array}{l}123.2 \\
(93.3)\end{array}$ & $\begin{array}{c}201.7 \\
(176.0)\end{array}$ \\
\hline Emission intensity & $\begin{array}{c}\mathrm{g} \mathrm{CO}_{2} \\
\text { eq. } \\
\mathrm{PLN}^{-1}\end{array}$ & $\begin{array}{c}410 \\
(300)\end{array}$ & $\begin{array}{c}40 \\
(40)\end{array}$ & $\begin{array}{c}230 \\
(120)\end{array}$ & $\begin{array}{c}440 \\
(270)\end{array}$ & $\begin{array}{c}510 \\
(330)\end{array}$ & $\begin{array}{c}490 \\
(450)\end{array}$ & $\begin{array}{c}390 \\
(320)\end{array}$ \\
\hline $\begin{array}{l}\text { Emission intensity } \\
\text { per ha }\end{array}$ & $\begin{array}{l}\mathrm{Mg} \mathrm{CO} \\
\text { eq. ha-1 }\end{array}$ & $\begin{array}{c}2.7 \\
(2.7)\end{array}$ & $\begin{array}{c}6.8 \\
(24.8)\end{array}$ & $\begin{array}{c}2.3 \\
(13.6)\end{array}$ & $\begin{array}{c}3.1 \\
(15.0)\end{array}$ & $\begin{array}{c}3.5 \\
(21.8)\end{array}$ & $\begin{array}{c}3.2 \\
(16.4)\end{array}$ & $\begin{array}{c}2.1 \\
(2.7)\end{array}$ \\
\hline $\begin{array}{l}\text { Emission intensity } \\
\text { per LU }\end{array}$ & $\begin{array}{l}\mathrm{Mg} \mathrm{CO} \\
\text { eq. } \mathrm{LU}^{-1}\end{array}$ & $\begin{array}{c}3.5 \\
(2.11)\end{array}$ & $\begin{array}{c}0.7 \\
(0.3)\end{array}$ & $\begin{array}{c}2.8 \\
(1.4)\end{array}$ & $\begin{array}{c}2.9 \\
(1.5)\end{array}$ & $\begin{array}{c}3.2 \\
(1.9)\end{array}$ & $\begin{array}{c}3.3 \\
(2.0)\end{array}$ & $\begin{array}{c}4.1 \\
(1.9)\end{array}$ \\
\hline
\end{tabular}

Source: Our own calculation based on FADN data 
transport sector was applied. The GHG emissions were calculated as a ratio of the quantity of fuel used and the emission factor. In our research, GHG emissions from the LULUCF sector were not included because the study concerns only one year. The main source of information used in the paper was data from the Polish FADN database on 2015 production. The farm samples were divided according to type of farming, economic size, and utilized agricultural area. Tables 3-5 present detailed farm characteristics in each grouping. The GHG emissions for all farms are expressed in $\mathrm{CO}_{2}$ equivalents. To assess the impact of farm activities on the environment, we applied the three GHG emission intensity indicators. The first presents the level of GHG emitted to produce each one PLN (polish currency). The second is GHG emissions per hectare of utilized area, and the third is GHG emissions per livestock unit. Data are presented as average values with standard deviation.

\section{Results and Discussion}

The average size of agricultural holdings in our sample amounted to 36 ha (Table 3). The UAA of farms with animal production was lower than average, but on a similar level (with the exception of poultry farms). The average size of poultry farms was $36 \%$ lower than average. The total outputs of animal farms were different. The values of farm production from the largest to the smallest were as follows: poultry $>$ pigs $>$ dairy $>$ mixed crop and livestock $>$ grazing livestock. The results show that farms specializing in pig production made better use of available land resources than dairy and grazing livestock farms. The GHG emissions related with animal production were the most important emission sources at the farm level. This is in agreement with calculations performed by Baldoni et al. [17]. Estimated GHG emissions in the studied farm types show that the highest emissions occurred in dairy farms, e.g., 180\% higher than in field crop farms. The farm types decided the share of each emission in total GHG emissions at a farm. In specialized animal farms, the emissions from livestock production ranged from 54 (pigs) to 67\% (dairy) (Fig. 1), whereas the contribution of fertilizers amounted to $15 \%$ in the dairy, grazing livestock, and poultry farms. In pig farms it was higher (33\%) because these farms applied more fertilizers to produce cereal for feeds. In field crop farms fertilizer emissions were about $65 \%$. Emission intensity differed across farm types whether financial output, UAA, or livestock unit (LU) was dominant. The highest emission intensity per 1 PLN was recorded in grazing livestock farms and was due to very low production values. In studies performed on Italian FADN the highest GHG emissions were also assessed for grazing livestock and dairy farms [17]. The mixed crops and livestock-type farms are more environmentally sustainable.

The shares of GHG emissions from animal production and fertilizers applied were 49 and $30 \%$, respectively (Fig. 1). Although emission intensities of these farms per

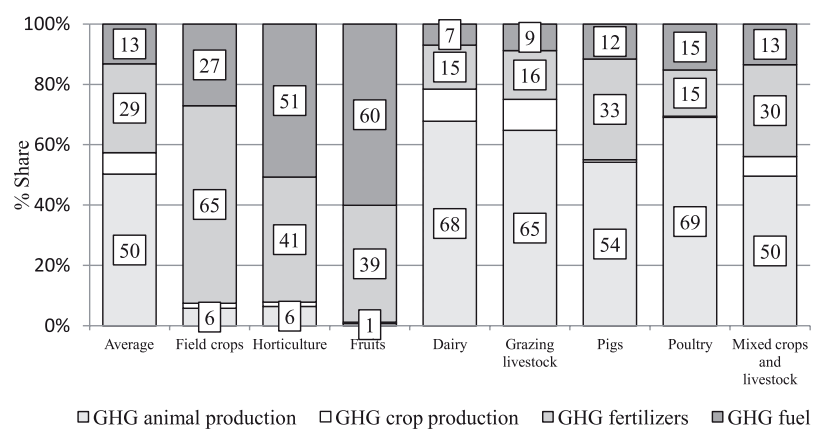

Fig. 1. Percentage share of animal, crop, fertilizer, and fuel GHG emissions at the farm level for different farm types.

UAA and LU were lower than those of specialized animal farms, the financial outputs of mixed farms were 30 and $32 \%$ lower, respectively, compared to dairy and field crop farms. The scale effect makes total financial output and GHG emissions grow with the size of agricultural holdings (Table 4). In our study, emission intensity per farm and LU increased from very small to medium-small farms. Then a decrease was recorded, which was a result of the higher increase of farm output and economic farm size. Our results are similar to those obtained by Baldoni et al. [17]. In their study, the medium farms were the highest emitters of GHG. Among very large farms poultry farms prevailed, which emitted less GHG per LU (0.7 Mg eq. $\left.\mathrm{CO}_{2} \mathrm{LU}^{-1}\right)$ and more per ha $\left(3.7 \mathrm{Mg}\right.$ eq. $\left.\mathrm{CO}_{2} \mathrm{LU}^{-1}\right)$ than other farms. Fig. 2 reveals the percentage share of animal, crop, fertilizer, and fuel GHG emissions at farm level for different economic farm sizes. The share of individual GHG emissions in all farms from the largest to the smallest was as follows: animal production $>$ fertilizers $>$ fuel $>$ crop production. GHG emissions from animal production varied from $40 \%$ in very small farms to $57 \%$ in very large. In all farms the share GHG emissions from crop production was below $8 \%$.

The scale effect related to production values and GHG emissions was analysed in relation to UAA. The growth of farm area affected increases in financial output and GHG emissions (Table 5). The highest emissions per ha were recorded for very small farms because in this group are classified poultry farms, which are

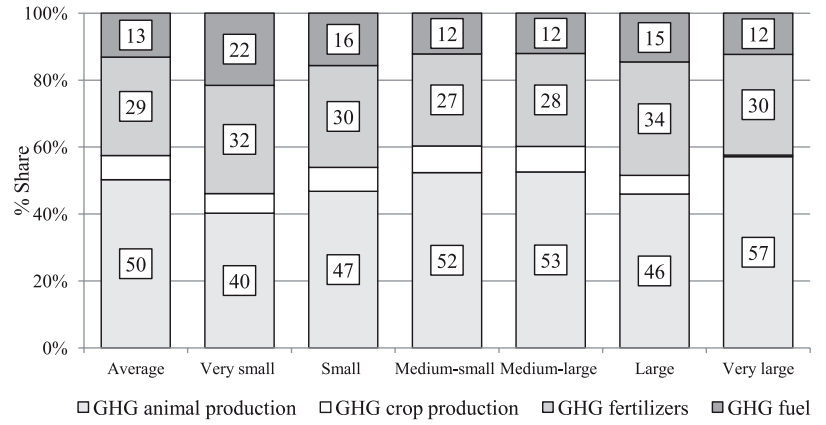

Fig. 2. Percentage share of animal, crop, fertilizer, and fuel GHG emissions at the farm level for different economic farm sizes. 


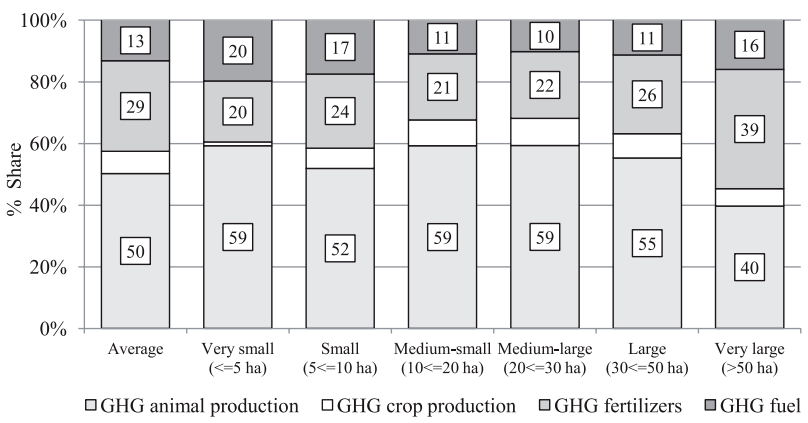

Fig. 3. Percentage share of animal, crop, fertilizer, and fuel GHG emissions at the farm level for farms divided according to utilized agricultural area.

characterized by high production value and small area of agricultural land. The emission intensity of small farms in Poland was on a similar level as small farms in Italy [17]. Emission intensity per ha of small farms was 2.3 $\mathrm{Mg} \mathrm{CO} 2$ eq. This value was similar to $\mathrm{GHG}$ emissions recorded for winter wheat production in field crop farms, where UAA was lower than 10 ha [18]. In our sample, the farms from 20 to 30 ha of UAA marked the highest emission intensity per PLN and LU. This was due to the fact that on these farms the number of animals was higher than the agricultural area. The share of GHG emissions from animal production in this group amounted to $60 \%$ (Fig. 3). Increases in UAA resulted in a decrease of GHG emissions from animal and crop production and growth of emissions from applied fertilizers and fuel. The presented results demonstrate that the FADN database has proved to be a valuable source of information in providing data required for assessing GHG emissions. This is an agreement with Dalgaared et al. [19], who concluded that FADN data could be applied to perform area-based environmental assessment, including farm emissions, which have an effect on the local environment. They also stated that there is a significant difference in resource use and emissions between farms of the same main enterprise, and for that reason it is insufficient to evaluation and compare agricultural products on case studies.

Most of the existing life cycle assessment (LCA) is based only on data from one or a few farms $[18,20]$. An important strength of the applied methodology is that all the farm types are representative because they use valid farm data from farm accounts. Additionally, the farm types created were based on accurate and welldocumented resources showing average production and efficiency levels within different farm types. The next strength of this method is a simple methodology, because only a few data are required, which allows us to measure the possibility of emissions reduction in a cost-effective manner. In effect, the farmer could control GHG emissions at the farm gate. Also, policy implemented at the farm level can be better evaluated without additional funds. The presented methodology is novel and contains some of issues that should be considered further in the work. Dick et al. [15] stated that national average emission factors can hide some farm level improvements and do not include new mitigation measures. The next issue, brought by Coderoni et al. [9], is how to count relatively immediate land-use change emissions over time. However, despite these weaknesses, the proposed methodology provides the opportunity to measure the possibility of reducing emission in a cost-effective manner.

\section{Conclusions}

The primary objective of our paper was to present the impact of conventional farms on the environment in Poland. Environmental performance was assessed by calculating GHG emissions and intensity indexes at the farm level based on the PL FADN database. The agricultural holdings were classified according to type of production, economic size, and utilized agricultural area. The comparable farms differed in their organization of production, productivity, and income. The results show that large variations in farms justify the microapproach of farm evaluation. Medium-small $(25 \leq €<50)$ and medium-large $(20 \leq \mathrm{UAA}<30)$ conventional dairy farm types were characterized by highest GHG emission intensity indexes compared to other farm types and sizes. The obtained indicators could be used by farm advisors to assess some aspects of environmental performance in an individual farm or group of farms. Additionally, they give a possibility to disseminate the best management practices that reduce GHG emissions. A methodology based on FADN could allow for an integrated assessment of GHG mitigation in a cost-effective manner because FADN data are collected for economic analysis.

\section{Acknowledgements}

Our studies were supported by National Centre for Research and Development within the project "Support for low carbon agriculture able to adopt to observed climate change in the perspective of 2030 and 2050".

\section{Rferences}

1. OLECKA A., BEBKIEWICZ K., DĘBSKI B., DZIECUCHOWICZ M., JĘDRYSIAK P., KANAFA I., KARGULEWICZ J., RUTKOWSKI J., SKOŚKIEWICZ S., WAŚNIEWSKA D., ZASINA M., ZIMAKOWSKA-LASKOWSKA M., ŻACZEK M. Poland's national inventory report 2016. National Centre for Emission Management. Warsaw, Poland. 2016.

2. EUROPEAN ENVIRONMENT AGENCY. Annual European Union greenhouse gas inventory 1990-2014 and inventory report 2016. 2016. EEA Report No15/2016. Copenhagen, Denmark. 2016.

3. EUROPEAN ENVIRONMENT AGENCY. Analysis of key trends and drivers in greenhouse gas emissions in the EU between 1990 and 2014. 2016. Copenhagen, Denmark. 2016. 
4. EUROPEAN UNION. Directive 2009/28/EC of the European Parliament and of the Council of 23 April 2009 on the promotion of the use of Energy from renewable sources and amending and subsequently repealing Directives 2001/77/EC and 2003/30/EC. Official J. European Union. 140, 16. 2009.

5. EUROPEAN COMMISSION. Proposal for a Regulation of the European Parliament and the Council on binding annual greenhouse gas emission reduction by Member States from 20121 to 2030 for a resilient Energy Union and to meet commitments under the Paris Agreement and amending Regulation No 525/2013 of the European Parliament and the Council on a mechanism for monitoring and reporting greenhouse gas emissions and other information relevant to climate change. COM (2016) 482 final. 2016.

6. EUROPEAN COMMISSION. A Road for moving to a competitive low carbon economy in 2050. Communication from the Commission to the European Parliament, the Council, the European Economic and Social Committee and the Committee of the Regions, COM (2011) 112 final. 2011.

7. IPCC. IPCC Guidelines for National Greenhouse gas Inventories In: Eggleston S., Buendia L., Miwa K., Ngara T., Tanabe K. (Eds.), Agriculture, Forsetry and Other Land Use, IGES, Japan, 4, 2006.

8. LOKUPITIYA E., PAUSTIAN K. Agricultural soil greenhouse gas emissions: a review of national inventory methods. J. Environ. Qual. 35, 1413, 2006.

9. CODERONI S., BONATI G., D'ANGELO L., LONGHITANO D., MAMBELLA M., PAPALEO A., VANINO S. Using FADN data to estimate agricultural greenhouse gases emissions at farm level. W: Vrolijk H. eds., Pacioli 20 (eds). Complex farms and sustainability in farm level data collection, LEI Proceedings 13-054, 2013.

10. NEVENS F., VERBRUGGEN I., REHEUL D., HOFMAN G. Farm gate nitrogen surpluses and nitrogen use efficiency of specialized dairy farms in Flanders: evolution and future goals. Agric. Syst. 88, 142, 2006.

11. WESTBURY D.B., PARK J.R., MAUCHLINE A.L., CRANE R.T., MORTIMER S.R. Assessing the environmental performance of UK arable and livestock holdings using data from the Farm Accountancy Data Network (FADN). J. Environ. Manage. 92, 902, 2011.

12. GERRARD C.L., PADEL S., MOAKES S. The use of Farm Business Survey data to compare the environmental performance of organic and conventional farms. International Journal of Agricultural Management. 2 (1), 5, 2012.
13. BUCKLEY C., WALL D.P., MORAN B., MURPHY P.N.C Developing the EU Farm Accountancy Data Network to derive indicators around the sustainable use of nitrogen and phosphorus at farm level. Nutr. Cycl. Agroecosyst. 102, 319, 2015.

14. CORSON M. S., RUAS J.F., LEVERT F., GUERRIER C., DUPRAZ P., VAN DER WERF H. Estimating emission inventories of French farms at multiple spatial scales using the Farm Accountancy Data Network (FADN), LCA Food 2010, Bari, Italy, 1, 103. 2010.

15. DICK J., SMITH P., SMITH R., LILLY A., MOXEY A., BOOTH J., CAMPBELL C. COULTER D. Calculating farm scale greenhouse gas emissions. University of Aberdeen, Carbon Plan, the Macaulay Institute, Pareto consulting, SAOS Ltd, Scotland, 2008.

16. FORSTER, P., RAMASWAMY V., ARTAXO P., BERNTSEN T., BETTS R., FAHEY D.W., HAYWOOD J., LEAN J., LOWE D.C., MYHRE, G., NGANGA J., PRINN R., RAGA G., SCHULZ M., VAN DORLAND R.: Changes in Atmospheric Constituents and in Radiative Forcing. In: Climate Change 2007: The Physical Science Basis. Contribution of Working Group I to the Fourth Assessment Report of the Intergovernmental Panel on ClimateChange [Solomon, S., D. Qin, M. Manning, Z. Chen, M. Marquis, K.B. Averyt, M.Tignor and H.L. Miller (eds.)]. Cambridge University Press, Cambridge, United Kingdom and New York, NY, USA, 2007.

17. BALDONI E., CODERONI S., ESPOSTI R., The productivity and environment nexus trough farm-level data. The case of carbon footprint applied to Lombardy FADN farms. XXXVII Conferenza Italiana di Scienze Regionali, Ancona 20-22 September 2016.

18. SYP A., FABER A., BORZĘCKA-WALKER M., OSUCH D. Assessment of greenhouse gas emissions in winter wheat farms using data envelopment analysis approach. Pol. J. Environ. Stud. 24 (5), 2197, 2015.

19. DALGAARD R., HALBERG N., KRISTENSEN IB S., LARSEN I. Modelling representative and coherent Danish farm types based on farm accountancy data for use in environmental assessments. Agric. Ecosyst. Environ. 117, 223, 2006.

20. BORZĘCKA-WALKER M., FABER A., PUDEŁKO R., KOZYRA J., SYP A., BOREK R. Life cycle assessment (LCA) of crops for energy production. J. Food Agric. Environ., 9 (3-4), 698, 2011. 